\title{
EFFECT OF MULTICARBOHYDRASE ENZYMES ON PERFORMANCE OF JAPANESE QUAIL FED OPTIMAL AND SUB- OPTIMAL ENERGY LEVELS
}

\author{
M.A.A. Abdel-Mageed; E.M. El-Kamash and Nadia, M.A. El-Bahy
}

Animal Prod. Res. Inst., Agric. Res. Center, Ministry of Agric, Doki, Giza, Egypt.

\section{ABSTRACT}

An on-farm experiment was conducted using 360 one-day old Japanese quail chicks which, individually wing-banded, weighed and randomly distributed into 4 experimental groups of similar mean body weight of 3 replicates each and aimed to study the possibility of improving the ME of SBM-based diets fed to Japanese quail (Coturnix coturnix japonica) by dietary addition of a commercial enzyme preparation "Xylam" 500 " at a level of $0.5 \mathrm{~kg} / \mathrm{ton}$ and its effect on growth performance, some carcass traits, intestinal viscosity and incidence of pasting vents and laying performance. Two experimental starter-grower corn-soybean meal diets (C-SBM) were formulated to be iso-nitrogenous (24\% $\mathrm{CP}$ ) and containing two $\mathrm{ME}$ levels $(2900 \& 2750 \mathrm{kcal} \mathrm{ME} / \mathrm{kg}$ diet). Also, two experimental CSBM layer basal diets were formulated to be iso-nitrogenous (20\% $\mathrm{CP})$ and containing two ME levels (2900 \& $2750 \mathrm{kcal} \mathrm{ME} / \mathrm{kg}$ diet). Four dietary treatments in both starting-growing and laying periods were compared; two treatments consisted of the two basal diets without "Xylam ${ }^{500 "}$ supplementation and two treatments consisted of the two basal diets supplemented with "Xylam ${ }^{500 "}$ " at a level of 0.5 $\mathrm{kg} / \mathrm{ton}$. Live growth performance, carcass characteristics, intestinal viscosity and incidence of pasting vents and laying performance were determined. Generally, supplementing Xylam ${ }^{500}$ to RE-diet gave equal performance to the corresponding Xylam ${ }^{500}$-free diet. But, supplementing Xylam ${ }^{500}$ to LE-diet significantly improved PI and GR, $\mathrm{EP} \%$, EN, EW, EM, FCR, carcass parameters \%, liver, heart and edible giblets \%. However, it significantly decreased MR \%, abdominal fat $\%$, the viscosity in different parts of intestine, pasting vents $\%$ and FI. Nutritionally, it could be concluded that supplementing "Xylam ${ }^{500 "}$ in both starter-grower and layer diets at a level of $0.5 \mathrm{~kg} /$ ton helped in improving quail performance, carcass traits and egg production traits.

Key words: Performance, growth, slaughter, carcass, intestinal viscosity, pasting vents, egg production and Japanese quail.

\section{INTRODUCTION}

The cost of poultry feeds is largely derived from the exorbitant feed ingredients prices, increasing competitive demand for them by man and animals and conventional ingredients scarcity (Apata and Ojo, 2000). Therefore, to reduce feed cost, which accounts for 65 to $70 \%$ of total production cost (Nworgu et al., 1999; Singh, 1990; Banerjee, 1992), research efforts are being geared towards supplementing SBM-based diets with multicarbohydrase enzymes.

Corn and soybean meal (SBM) are the backbone in poultry diets for their high available energy and protein, respectively. They contain 9.7 and $21.7 \%$

Fayoum J. Agric. Res. \& Dev., Vol. 27, No.1, January, 2013 
non-starch polysaccharides (NSP), respectively (Knudsen, 2001). The action of NSP in poultry digestive system is essentially a physical one in which plant cell wall either acts as barrier to nutrients release from cell or increase digesta viscosity restricting their absorption (Knudsen, 1997). It also contributes to dropping stickiness, which can cause footpad disorders (Abbott et al., 1969; Jensen et al., 1970). Studies on metabolizable energy indicaeted that SBM and dehulled SBM contain about 5-6\% more gross energy than corn; however, they contain 54 and $42 \%$; respectively, less metabolizable energy than corn (Hill et al., 1960; Hill and Renner, 1960; Potter and Matterson, 1960; Sibbald and Slinger, 1962), indicating that some components of SBM are poorly digested and metabolized.

This highlights the opportunity for using feed enzymes in SBM-based diets. Many attempts has been made to cut feeding cost down to the minimum levels by supplementing SBM-based diets with multicarbohydrase enzymes and their effect on growth performance, some carcass traits, some blood parameters, and economical efficiency. Among the important attempts made to minimize the feeding cost is the present study which was designed to study the possibility of improving energy and nutrients bioavailability of SBM-based diets fed to Japanese quail (Coturnix coturnix japonica) by dietary addition of Xylam ${ }^{500}$, an enzymatic preparation containing $\beta$-xylanase $(1260 \mathrm{U})$ and $\alpha$-amylase $(8000 \mathrm{U})$, and to test its effect on growth performance, some carcass traits and egg production traits.

\section{MATERIALS AND METHODS}

This study was carried out at the poultry farm, Faculty of Agriculture, Fayoum University, during the period from November (2011) to March (2012).

\section{Experimental birds and housing}

Three hundred and sixty unsexed one-day old Japanese quail chicks with an average body weight of $7.21 \pm 0.05 \mathrm{~g}$ were used in a 42-day growing trial. Chicks were individually wing-banded, weighed, randomly distributed into four equal experimental groups of similar mean weight of 90 chicks each, which consists of three replicates of 30 chicks each. At 42 days of age, birds were transferred to layer quail cages for a 90-day laying trial.

\section{Experimental diets, design and treatments}

Two starter-grower corn-soybean meal (C-SBM) basal diets were formulated to be iso-nitrogenous $(24 \%$ CP) and containing 2900 (recommended energy, RE-diet) and 2750 (low energy, LE-diet) kcal $\mathrm{ME} / \mathrm{kg}$ diet. Also, two C-SBM layer basal diets were formulated to be isonitrogenous (20\% CP) and containing 2900 (recommended energy, RE-diet) and 2750 (low energy, LE-diet) $\mathrm{kcal} \mathrm{ME} / \mathrm{kg}$ diet.

A commercial enzyme cocktail preparation, Xylam ${ }^{500}$, was added at two levels of 0 and $0.5 \mathrm{~kg} / \mathrm{ton}$ diet. Dietary treatments were designed in a $2 \times 2$ factorial arrangement of two ME levels (2900 and $2750 \mathrm{kcal} / \mathrm{kg}$ diet) and two enzyme levels ( 0 and $0.5 \mathrm{~kg} /$ ton of feed. Thus, this supplementation resulted in four dietary treatments in both starting-growing and laying periods. The composition and chemical analysis of the experimental diets are shown in Table (1).

\section{Management}

During the experimental period, birds were exposed to similar care and management in all treatment groups. Ambient temperature was maintained

Fayoum J. Agric. Res. \& Dev., Vol. 27, No.1, January, 2013 
EFFECT OF MULTICARBOHYDRASE ENZYMES ON............ 3

3

at 33-34 ${ }^{\circ} \mathrm{C}$ during the $1^{\text {st }}$ week and was decreased by $2{ }^{\circ} \mathrm{C}$ weekly for the next 3 weeks. During the $5^{\text {th }}$ and $6^{\text {th }}$ week temperature was maintained at 22$24{ }^{\circ} \mathrm{C}$. Birds were received continuous artificial lighting daily during growing trial and $17 \mathrm{~h}$ afterwards. Chicks were fed the starter-grower diets from one day to 6 week and the layer diets from 7 to 19 week of age. Mash feed and clean fresh tap water were provided ad liblitum.

\section{Measurements and data collection}

Growth performance:

Individual body weight (BW, g) and feed intake (FI, g/bird) were weekly recorded to determine body weight gain $(\mathrm{BWG}, \mathrm{g}$ ) [ gain = final weight $(\mathrm{g})-$ initial weight $(\mathrm{g})]$. Feed conversion ratio (FCR, g feed/g gain) and caloric conversion ratio (CCR) were also calculated for the starting-growing period.

Performance index (PI) for the starting-growing period, was calculated according the equation reported by North (1981), PI $=[(\mathrm{BW}, \mathrm{kg} / \mathrm{FC}) \mathrm{x}$ $100]$. Growth rate (GR) for the starting-growing period was also calculated, $\mathrm{GR}=[($ final $\mathrm{BW}-$ initial $\mathrm{BW}) / 0.5$ (initial $\mathrm{BW}+$ final $\mathrm{BW})] \times 100$. Mortality rate \% (MR) was also calculated.

Intestinal fluid viscosity:

At 14 days of age, two birds per replicate were killed and individual digesta samples were collected from each segment of the intestine (duodenum, jejunum and ileum), weighed and kept on ice before centrifugation at $12,000 \times g$ for 10 minute. The supernatant obtained from each sample were stored separately at $-20{ }^{\circ} \mathrm{C}$ until use. The supernatants were thawed and the viscosity of the supernatant $(0.5 \mathrm{~mL})$, expressed as centipoises (cP), was immediately measured with a digital viscometer.

\section{Carcass parameters:}

At the end of the starting-growing period (42 days), 24 birds $(3 \hat{0}+3$ o/treatment) with BW similar to the mean were slaughtered to determine carcass characteristics. Obtained criteria were dressing breast and thighs weights. Abdominal fat was removed from the gizzard and abdominal region and individually weighed for each carcass. Edible giblets (liver, heart, gizzard and total edible giblets) were individually separated, weighed and calculated for each organ as \% of live BW.

\section{Egg production traits:}

Daily egg number $(\mathrm{EN})$ and egg weight $(\mathrm{EW}, \mathrm{g})$ as well as weekly feed intake (FI, g/bird) was recorded. Egg production (EP, \%), egg mass (EM, g) and feed conversion ratio (FCR, $\mathrm{g}$ feed/g egg) were calculated per each replicate and treatment from 7 to 19 weeks of age.

\section{Chemical analysis:}

Experimental diets were analyzed according to the following procedures detailed by the Association of Official Analytical Chemists (AOAC, 1990) for crude protein $(\mathrm{CP})$, crude fiber $(\mathrm{CF})$ and ether extract (EE). Metabolizable energy (ME) of experimental diets was calculated considering the ME values of different feed ingredients according to the Feed Composition Tables for Animal and Poultry Feedstuffs Used in Egypt (2001).

Statistical analysis:

Obtained data were expressed as means \pm standard error and statistically analyzed by analysis of variance as a factorial arrangement of $2 \times 2$ according to Steel and Torrie (1980). Also, the General Linear Method

Fayoum J. Agric. Res. \& Dev., Vol. 27, No.1, January, 2013 
M.A.A. Abdel-Mageed; et al.

procedure of SPSS. (1993) computer statistical program for MS Windows release 6.0 was used. The significant means were ranked using Duncan's Range Test (Duncan, 1955).

\section{RESULTS AND DISCUSSION \\ Growth performance:}

The results for live growth performance in terms of initial BW, final BW, BWG, FI, FCR and CCR during the whole experimental period are shown in Table (2).

With regard to $\mathrm{ME}$ levels, it was noticed that feeding RE-diets significantly improved final BW, BWG, FCR and CCR but significantly decreased FI in comparison to LE-diets. Regarding enzymatic preparation, feeding Xylam ${ }^{500}$-supplemented diets gave significant improvement in BW, BWG, FCR and CCR but significantly decreased FI in comparison to Xylam ${ }^{500}$-free diets. With respect to the interaction between ME level and enzymatic preparation, using Xylam ${ }^{500}$ with RE-diet did not exert any significant effect in $\mathrm{BW}, \mathrm{BWG}, \mathrm{FI}, \mathrm{FCR}$ and $\mathrm{CCR}$ as compared to the corresponding Xylam ${ }^{500}$-free diet. On the other hand, supplementing Xylam ${ }^{500}$ to LE-diet gave equal performance to the corresponding Xylam ${ }^{500}$-free diet.

The present study indicated that the improved values of BW in case of supplementing Xylam ${ }^{500}$ to LE-diet were greater than that of the corresponding Xylam ${ }^{500-}$ free diet. This agreed with that reported by Kocher et al. (2003). Moreover, Cowan et al. (1996) mentioned that enzyme supplementation to low nutrient level diets had greater beneficial effect than supplementation to high nutrient level diets. This will be practicable for producers to reduce the apparent metabolizable energy of diets by 3 to $4 \%$ in feed formulas and therefore has a cost benefit. The improvement in BWG and FCR in this study is in agreement with those of Jackson et al. (2004) and Abdel-Mageed (2012). However, these results are in disagreement with those of Waldroup et al. (2006) and Marsman et al. (1997) who found that the inclusion of commercial enzyme complexes containing multicarbohydrase activities did not produce an improvement in growth performance of birds fed SBM-based diets. The improvement in FCR can mainly be attributed to better energy utilization than the unsupplemented Xylam ${ }^{500}$ diet and perhaps changes in intestinal viscosity.

\section{Performance index, growth rate and mortality rate:} Table (3).

The mean values of PI, GR values as well as MR \% are given in

With regard to ME levels, it was observed that feeding RE-diets resulted in significant improvement in PI and GR and significant decrease in MR \% as compared to LE-diets. Regarding enzymatic preparation, feeding Xylam ${ }^{500}$-supplemented diets gave significant improvement in PI and GR and significant decrease in MR \% in comparison to Xylam ${ }^{500}$-free diets. With respect to the interaction between $\mathrm{ME}$ level and enzymatic preparation, using Xylam ${ }^{500}$ with RE-diet had no significant effect on PI and GR, whereas it significantly decreased MR \% as compared to the corresponding Xylam ${ }^{500^{-}}$ free diet. While, supplementing Xylam ${ }^{500}$ to LE-diet significantly improved PI and GR, whereas it significantly decreased MR \% as compared to the corresponding Xylam ${ }^{500}$-free diet.

Fayoum J. Agric. Res. \& Dev., Vol. 27, No.1, January, 2013 


\section{Carcass parameters}

The percentages of dressing, breast, thighs and abdominal fat are summarized in Table (4).

With regard to ME levels, it was noticed that feeding RE-diets caused significant increase in carcass parameters, the only exception was for abdominal fat that did not significantly differ as compared to LE-diets. Regarding enzymatic preparation, feeding Xylam ${ }^{500}$-supplemented diets gave significant increase in dressing, breast and thighs $\%$ as well as significant decrease in abdominal fat $\%$ in comparison to Xylam ${ }^{500}$-free diets. With respect to the interaction between $\mathrm{ME}$ level and enzymatic preparation, using Xylam ${ }^{500}$ with RE-diet did not exert any significant effect in carcass parameters $\%$ except for abdominal fat $\%$ that was significantly decreased as compared to the corresponding Xylam ${ }^{500}$-free diet. However, supplementing Xylam ${ }^{500}$ to LE-diet had significantly increased carcass parameters $\%$, but it significantly decreased abdominal fat $\%$ as compared to the corresponding Xylam ${ }^{500}$-free diet.

The present result of improving breast \% agreed with that reported by Lamptey et al. (2001) and Abdel-Mageed (2012) but it was disagreement with that of Kidd $\boldsymbol{e t}$ al. (2001) who demonstrated that enzyme supplementation to diets has no effect on breast meat yield. The improvement of breast yield may be interpreted by the utilization of nutrients liberated from the nondigestible compounds of corn and soybean meal diet due to Xylam ${ }^{500}$ supplementation.

\section{Edible giblets:}

The percentages of edible giblets in terms of liver, heart, gizzard and total edible giblets at 6 week of age are given in Table (5).

There was no significant response obtained for ME levels, enzyme supplementation or their interaction in gizzard \%. Regarding ME levels, it was noticed that feeding RE-diets caused significant increase in liver, heart and total edible giblets \% in comparison to LE-diets. Concerning enzymatic preparation, feeding Xylam ${ }^{500}$-supplemented diets gave significant increase in liver, heart and total edible giblets \% in comparison to LE-diets. With respect to the interaction between $\mathrm{ME}$ level and enzymatic preparation, using Xylam ${ }^{500}$ with RE-diet did not cause significant change in liver, heart and edible giblets $\%$ as compared to the corresponding Xylam ${ }^{500}$-free diet. However, supplementing Xylam ${ }^{500}$ to LE-diet had significantly increased liver, heart and edible giblets $\%$ as compared to the corresponding Xylam ${ }^{500}$ free diet. This agreed with that reported by Abdel-Mageed (2012).

The aforementioned reduction of the relative weights of liver and heart are in disagreement with the results of Tahir et al. (2005) who showed that enzyme treatments did not affect the relative weight of liver. Gracia $\boldsymbol{e t}$ al. (2003) reported that enzyme has no effect on the relative weights of digestive organs.

The lack of response in relative weight of gizzard is in disagreed with the results of Brenes et al. (1993) who found that the relative weight of gizzard was reduced by enzyme treatment.

\section{Intestinal fluid viscosity:}

The mean values of viscosity in different parts of intestine and incidence of pasting vents at 7 and 14 days of age are summarized in Table (6).

Fayoum J. Agric. Res. \& Dev., Vol. 27, No.1, January, 2013 
With regard to ME levels, it was observed that feeding RE-diets did not exert any significant effect in the viscosity in different parts of intestine; however it significantly increased the pasting vents \% compared with LEdiets. With respect to enzymatic preparation, feeding Xylam ${ }^{500}$-supplemented diets significantly decreased the viscosity in different parts of intestine and pasting vents $\%$ compared with Xylam ${ }^{500}$-free diets. Regarding the interaction between ME level and enzymatic preparation, using Xylam ${ }^{500}$ with either REor LE-diet significantly decreased the viscosity in different parts of intestine and pasting vents \% compared with the corresponding Xylam ${ }^{500}$-free diet.

Increasing viscosity of intestinal fluid inhibits the absorption of nutrients by decreasing the gastrointestinal passage rate. Enzymes supplementation act to decrease the viscosity of intestinal fluid, which results in improving the digestion and absorption process by increasing the gastrointestinal passage rate and increasing the diffusion of digestive enzymes and the secretion of endogenous enzymes (Van der Klis et al., 1993 and AbdelMageed., 2012).

\section{Laying performance:}

Results concerning laying performance in terms of FI, EP \%, EN, EW, EM and FCR values are shown in Table (7).

With regard to ME levels, it was noticed that feeding RE-diets caused significant improvement in EP \%, EN, EW, EM and FCR, but it significantly decreased FI compared with LE-diets. With respect to enzymatic preparation, feeding Xylam ${ }^{500}$-supplemented diets significantly improved EP \%, EN, EW, EM and FCR, but it significantly decreased FI compared with Xylam ${ }^{500}$-free diets. Regarding the interaction between ME level and enzymatic preparation, using Xylam ${ }^{500}$ with RE-diet did not exert any significant effect in FI, EP \%, EN, EW, EM and FCR compared with the corresponding Xylam ${ }^{500}$-free diet. However, supplementing Xylam ${ }^{500}$ to LE-diet had significantly improved EP \%, EN, EW, EM and FCR, but it significantly decreased FI as compared to the corresponding Xylam ${ }^{500}$-free diet. This agreed with that reported by Abdel-Mageed (2012).

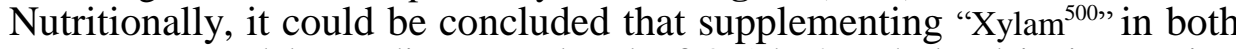
starter-grower and layer diets at a level of $0.5 \mathrm{~kg} / \mathrm{ton}$ helped in improving quail performance, carcass traits and egg production traits. 
Table (1): Composition and calculated analysis of the experimental starter-grower and layer basal diets.

\begin{tabular}{|c|c|c|c|c|}
\hline \multirow{3}{*}{ Ingredients } & \multicolumn{4}{|c|}{ Percentage $(\%)$} \\
\hline & \multicolumn{2}{|c|}{ Starter-grower basal diets ${ }^{*}$} & \multicolumn{2}{|c|}{ Layer basal diets } \\
\hline & RE-diet & LE-diet & RE-diet & LE-diet \\
\hline Yellow Corn, ground & 54.27 & 50.64 & 58.45 & 53.70 \\
\hline Soybean meal (44\% CP) & 35.00 & 38.23 & 25.80 & 27.34 \\
\hline Corn gluten meal $(62 \%$ CP) & 7.14 & 4.37 & 6.70 & 4.90 \\
\hline Wheat bran & 0.00 & 3.80 & 0.00 & 5.30 \\
\hline Vegetable oil & 0.50 & 0.00 & 1.30 & 1.10 \\
\hline Dicalcium phosphate & 0.75 & 0.70 & 1.10 & 1.05 \\
\hline Limestone & 1.35 & 1.35 & 5.70 & 5.70 \\
\hline Common salt (NaCl) & 0.34 & 0.34 & 0.34 & 0.34 \\
\hline Premix $^{* *}$ & 0.30 & 0.30 & 0.30 & 0.30 \\
\hline DL-Methionine & 0.04 & 0.07 & 0.05 & 0.07 \\
\hline L-Lysine & 0.11 & 0.00 & 0.06 & 0.00 \\
\hline Choline chloride & 0.20 & 0.20 & 0.20 & 0.20 \\
\hline Total & 100.00 & 100.00 & 100.00 & 100.00 \\
\hline \multicolumn{5}{|l|}{ Determined values (\%) } \\
\hline CP \% & 24.01 & 24.00 & 20.01 & 20.00 \\
\hline CF \% & 3.95 & 4.46 & 3.36 & 3.91 \\
\hline EE \% & 2.74 & 2.61 & 2.76 & 2.58 \\
\hline \multicolumn{5}{|l|}{ Calculated values ${ }^{* * * *}$} \\
\hline ME (kcal/kg) & 2903 & 2759 & 2890 & 2750 \\
\hline Ca \% & 0.80 & 0.80 & 2.50 & 2.50 \\
\hline Av. Phosphorus \% & 0.30 & 0.30 & 0.35 & 0.35 \\
\hline L-Lysine \% & 1.30 & 1.30 & 1.00 & 1.01 \\
\hline DL-Methionine \% & 0.50 & 0.50 & 0.45 & 0.45 \\
\hline Methionine + Cyst \% & 1.00 & 1.00 & 0.80 & 0.84 \\
\hline
\end{tabular}

*Starter-grower and layer basal diets were assigned to 2 levels of "Xylam" ${ }^{500 "}$ enzyme preparation $(0$ \& 0.5 $\mathrm{kg} /$ ton diet).

**Vitamins and minerals premix provides per kg of diet: $10000 \mathrm{IU}$ vit. A, $11.0 \mathrm{IU}$ vit. $\mathrm{E}, 1.1 \mathrm{mg}$ vit. $\mathrm{K}$, $1100 \mathrm{ICU}$ vit. $\mathrm{D}_{3}, 5 \mathrm{mg}$ riboflavin, $12 \mathrm{mg}$ Ca pantothenate, $12.1 \mu \mathrm{g}$ vit. $\mathrm{B}_{12}, 2.2 \mathrm{mg}$ vit. $\mathrm{B}_{6}, 2.2 \mathrm{mg}$ thiamin, $44 \mathrm{mg}$ nicotinic acid, $250 \mathrm{mg}$ choline chloride, $1.55 \mathrm{mg}$ folic acid, $0.11 \mathrm{mg}$ d-biotin, $60 \mathrm{mg} \mathrm{Mn}, 50 \mathrm{mg} \mathrm{Zn}$, $0.3 \mathrm{mg} \mathrm{I}, 0.1 \mathrm{mg} \mathrm{Co}, 30 \mathrm{mg} \mathrm{Fe}, 5 \mathrm{mg} \mathrm{Cu}$ and $1 \mathrm{mg} \mathrm{Se}$.

***According to Feed Composition Tables for animal \& poultry feedstuffs used in Egypt (2001). 
Table (2): Effect of dietary treatments on performance of growing Japanese quail at 0 - 6 weeks of age.

\begin{tabular}{|c|c|c|c|c|c|c|}
\hline $\begin{array}{l}\text { Treatments } \\
(24 \% \text { CP })\end{array}$ & $\begin{array}{c}\text { Initial } \\
\text { BW } \\
\text { (g/bird) }\end{array}$ & $\begin{array}{c}\text { Final } \\
\text { BW } \\
\text { (g/bird) }\end{array}$ & $\begin{array}{c}\text { BWG } \\
\text { (g/bird/35 d) }\end{array}$ & $\begin{array}{c}\text { FI } \\
(\text { g/bird/35 d) }\end{array}$ & $\begin{array}{c}\text { FCR } \\
\text { (Feed: } \\
\text { gain) }\end{array}$ & $\begin{array}{c}\text { CCR } \\
\text { (Calorie: } \\
\text { gain) }\end{array}$ \\
\hline \multicolumn{7}{|c|}{$\begin{array}{c}\text { Energy effects } \\
\end{array}$} \\
\hline 2900(kcal/kg diet) & $7.21 \pm 0.07$ & $192.31 \pm 1.34^{\mathrm{A}}$ & $185.10 \pm 1.11^{\mathrm{A}}$ & $453.18 \pm 3.06^{\mathrm{B}}$ & $2.59 \pm 0.09^{\mathrm{B}}$ & $7.10 \pm 0.04^{\mathrm{B}}$ \\
\hline 2750(kcal/kg diet) & $7.21 \pm 0.10$ & $178.93 \pm 1.41^{\mathrm{B}}$ & $171.72 \pm 1.09^{\mathrm{B}}$ & $476.12 \pm 2.91^{\mathrm{A}}$ & $2.79 \pm 0.05^{\mathrm{A}}$ & $7.66 \pm 0.06^{\mathrm{A}}$ \\
\hline \multicolumn{7}{|c|}{ Enzyme effects } \\
\hline Xylam $^{500}(0.0 \mathrm{~kg} / \mathrm{kg}$ diet $)$ & $7.19 \pm 0.09$ & $179.18 \pm 1.26^{\mathrm{B}}$ & $171.99 \pm 1.15^{\mathrm{B}}$ & $473.67 \pm 2.23^{\mathrm{A}}$ & $2.78 \pm 0.07^{\mathrm{A}}$ & $7.81 \pm 0.10^{\mathrm{A}}$ \\
\hline $\mathrm{Xylam}^{500}(0.5 \mathrm{~kg} / \mathrm{kg}$ diet $)$ & $7.23 \pm 0.06$ & $192.06 \pm 1.40^{\mathrm{A}}$ & $184.83 \pm 1.23^{\mathrm{A}}$ & $455.64 \pm 2.12^{\mathrm{B}}$ & $2.60 \pm 0.10^{\mathrm{B}}$ & $6.96 \pm 0.11^{\mathrm{B}}$ \\
\hline \multicolumn{7}{|c|}{$\begin{array}{c}\text { Interaction } \\
\end{array}$} \\
\hline $2900 \times 0.0$ & $7.18 \pm 0.04$ & $190.25 \pm 1.14^{\mathrm{a}}$ & $183.07 \pm 1.13^{\mathrm{a}}$ & $457.20 \pm 2.21^{b}$ & $2.50 \pm 0.12^{\mathrm{b}}$ & $7.24 \pm 0.08^{b}$ \\
\hline $2900 \times 0.5$ & $7.24 \pm 0.08$ & $194.37 \pm 1.10^{\mathrm{a}}$ & $187.13 \pm 1.04^{\mathrm{a}}$ & $449.16 \pm 2.18^{\mathrm{b}}$ & $2.67 \pm 0.07^{b}$ & $6.96 \pm 0.04^{\mathrm{b}}$ \\
\hline $2750 \times 0.0$ & $7.20 \pm 0.06$ & $168.10 \pm 1.13^{\mathrm{b}}$ & $160.90 \pm 1.14^{\mathrm{b}}$ & $490.13 \pm 3.04^{\mathrm{a}}$ & $3.05 \pm 0.10^{\mathrm{a}}$ & $8.37 \pm 0.06^{\mathrm{a}}$ \\
\hline $2750 \times 0.5$ & $7.22 \pm 0.03$ & $189.75 \pm 1.12^{\mathrm{a}}$ & $182.53 \pm 1.07^{\mathrm{a}}$ & $462.11 \pm 2.19^{b}$ & $2.53 \pm 0.13^{b}$ & $6.95 \pm 0.05^{\mathrm{b}}$ \\
\hline
\end{tabular}

Means in the same column within the same effect having different letters are significantly different at $\mathrm{P} \leq$ 0.05 .

$\mathrm{BW}=$ Body weight

$\mathrm{BWG}=$ Body weight gain

$\mathrm{FI}=$ Feed intake

$\mathrm{FCR}=$ Feed conversion ratio

$\mathrm{CCR}=$ caloric conversion ratio

Table (3): Effect of dietary treatments on performance index, growth rate and mortality rate of Japanese quail at $0-6$ weeks of age.

\begin{tabular}{|c|c|c|c|}
\hline Items & PI & GR & $\begin{array}{l}\text { MR } \\
(\%)\end{array}$ \\
\hline \multicolumn{4}{|c|}{ Energy effects } \\
\hline 2900 (kcal/kg diet) & $7.45 \pm 0.11^{\mathrm{A}}$ & $185.55 \pm 0.14^{\mathrm{A}}$ & $5.83 \pm 0.04^{\mathrm{B}}$ \\
\hline 2750 (kcal/kg diet) & $6.51 \pm 0.13^{\mathrm{B}}$ & $184.46 \pm 0.20^{\mathrm{B}}$ & $8.34 \pm 0.05^{\mathrm{A}}$ \\
\hline \multicolumn{4}{|c|}{ Enzyme effects } \\
\hline Xylam $^{500}(0.0 \mathrm{~kg} / \mathrm{kg}$ diet $)$ & $6.56 \pm 0.09^{\mathrm{B}}$ & $184.51 \pm 0.11^{\mathrm{B}}$ & $10.00 \pm 0.07^{\mathrm{A}}$ \\
\hline $\mathrm{Xylam}^{500}(0.5 \mathrm{~kg} / \mathrm{kg}$ diet $)$ & $7.39 \pm 0.05^{\mathrm{A}}$ & $185.49 \pm 0.10^{\mathrm{A}}$ & $4.17 \pm 0.05^{\mathrm{B}}$ \\
\hline \multicolumn{4}{|c|}{ Interaction } \\
\hline $2900 \times 0.0$ & $7.61 \pm 0.07^{\mathrm{a}}$ & $185.45 \pm 0.16^{\mathrm{a}}$ & $8.33 \pm 0.04^{\mathrm{b}}$ \\
\hline $2900 \times 0.5$ & $7.28 \pm 0.10^{\mathrm{a}}$ & $185.64 \pm 0.13^{\mathrm{a}}$ & $3.33 \pm 0.06^{\mathrm{d}}$ \\
\hline $2750 \times 0.0$ & $5.51 \pm 0.12^{\mathrm{b}}$ & $183.57 \pm 0.08^{b}$ & $11.67 \pm 0.05^{\mathrm{a}}$ \\
\hline $2750 \times 0.5$ & $7.50 \pm 0.10^{\mathrm{a}}$ & $185.34 \pm 0.23^{\mathrm{a}}$ & $5.00 \pm 0.03^{\mathrm{c}}$ \\
\hline
\end{tabular}

Means in the same column within the same effect having different letters are significantly different at $\mathrm{P} \leq 0.05$.
$\mathrm{PI}=$ Performance index
$\mathrm{GR}=$ Growth rate
$\mathrm{MR}=$ mortality rate

Fayoum J. Agric. Res. \& Dev., Vol. 27, No.1, January, 2013 
Table (4): Effect of dietary treatments on carcass characteristics of Japanese quail at 6 weeks of age.

\begin{tabular}{|c|c|c|c|c|}
\hline \multirow{2}{*}{$\underbrace{\text { Items }}_{\begin{array}{l}\text { Treatments } \\
(24 \% \mathrm{CP})\end{array}}$} & \multicolumn{4}{|c|}{$(\%$ of $\mathrm{BW})$} \\
\hline & Dressing ${ }^{*}$ & Breast & Thighs & $\begin{array}{c}\text { Abdominal } \\
\text { fat }\end{array}$ \\
\hline \multicolumn{5}{|c|}{$\begin{array}{c}\text { Energy effects } \\
\end{array}$} \\
\hline 2900 (kcal/kg diet) & $76.89 \pm 0.41^{\mathrm{A}}$ & $37.67 \pm 0.34^{\mathrm{A}}$ & $23.84 \pm 0.13^{\mathrm{A}}$ & $1.13 \pm 0.03$ \\
\hline 2750 (kcal/kg diet) & $75.40 \pm 0.29^{\mathrm{B}}$ & $35.80 \pm 0.20^{\mathrm{B}}$ & $22.11 \pm 0.10^{\mathrm{B}}$ & $1.14 \pm 0.01$ \\
\hline \multicolumn{5}{|c|}{ Enzyme effects } \\
\hline Xylam $^{500}(0.0 \mathrm{~kg} / \mathrm{kg}$ diet $)$ & $75.06 \pm 0.33^{\mathrm{B}}$ & $35.50 \pm 0.42^{\mathrm{B}}$ & $21.91 \pm 0.11^{\mathrm{B}}$ & $1.20 \pm 0.02^{\mathrm{A}}$ \\
\hline Xylam $^{500}(0.5 \mathrm{~kg} / \mathrm{kg}$ diet $)$ & $77.23 \pm 0.10^{\mathrm{A}}$ & $37.97 \pm 0.10^{\mathrm{A}}$ & $24.04 \pm 0.14^{\mathrm{A}}$ & $1.08 \pm 0.01^{\mathrm{B}}$ \\
\hline \multicolumn{5}{|c|}{ Interaction } \\
\hline $2900 \times 0.0$ & $76.35 \pm 0.24^{\mathrm{a}}$ & $37.23 \pm 0.34^{\mathrm{a}}$ & $23.71 \pm 0.12^{\mathrm{a}}$ & $1.20 \pm 0.02^{\mathrm{a}}$ \\
\hline $2900 \times 0.5$ & $77.42 \pm 0.35^{\mathrm{a}}$ & $38.10 \pm 0.27^{\mathrm{a}}$ & $23.96 \pm 0.13^{\mathrm{a}}$ & $1.06 \pm 0.01^{\mathrm{b}}$ \\
\hline $2750 \times 0.0$ & $73.77 \pm 0.16^{b}$ & $33.76 \pm 0.45^{\mathrm{b}}$ & $20.10 \pm 0.10^{\mathrm{b}}$ & $1.19 \pm 0.01^{\mathrm{a}}$ \\
\hline $2750 \times 0.5$ & $77.03 \pm 0.32^{\mathrm{a}}$ & $37.84 \pm 0.13^{\mathrm{a}}$ & $24.12 \pm 0.14^{\mathrm{a}}$ & $1.09 \pm 0.02^{\mathrm{b}}$ \\
\hline
\end{tabular}

$*$ Dressing $\%=[($ Carcass weight + Giblets weight $) /($ Pre-slaughter weight $)] \times 100$.

Means in the same column within the same effect having different letters are significantly different at $\mathrm{P} \leq 0.05$.

Table (5): Effect of dietary treatments on edible giblets \% of Japanese quail at 6 weeks of age.

\begin{tabular}{|c|c|c|c|c|}
\hline \multirow[t]{2}{*}{ Items } & \multicolumn{3}{|c|}{ Edible giblets $(\%)$} & \multirow{2}{*}{$\begin{array}{c}\text { Total edible } \\
\text { giblets } \\
(\%)\end{array}$} \\
\hline & $\begin{array}{c}\text { Liver } \\
(\%)\end{array}$ & $\begin{array}{c}\text { Heart } \\
(\%)\end{array}$ & $\begin{array}{c}\text { Gizzard } \\
(\%)\end{array}$ & \\
\hline \multicolumn{5}{|c|}{ Energy effects } \\
\hline 2900 (kcal/kg diet) & $2.50 \pm 0.14^{\mathrm{A}}$ & $1.44 \pm 0.09^{\mathrm{A}}$ & $2.02 \pm 0.13$ & $5.95 \pm 0.12^{\mathrm{A}}$ \\
\hline 2750 (kcal/kg diet) & $2.15 \pm 0.10^{\mathrm{B}}$ & $1.22 \pm 0.05^{\mathrm{B}}$ & $2.07 \pm 0.10$ & $5.44 \pm 0.10^{\mathrm{B}}$ \\
\hline \multicolumn{5}{|c|}{ Enzyme effects } \\
\hline Xylam $^{500}(0.0 \mathrm{~kg} / \mathrm{kg}$ diet $)$ & $2.16 \pm 0.06^{\mathrm{B}}$ & $1.23 \pm 0.10^{\mathrm{B}}$ & $2.03 \pm 0.11$ & $5.42 \pm 0.13^{\mathrm{B}}$ \\
\hline Xylam $^{500}(0.5 \mathrm{~kg} / \mathrm{kg}$ diet $)$ & $2.48 \pm 0.11^{\mathrm{A}}$ & $1.43 \pm 0.08^{\mathrm{A}}$ & $2.07 \pm 0.09$ & $5.97 \pm 0.11^{\mathrm{A}}$ \\
\hline \multicolumn{5}{|c|}{ Interaction } \\
\hline $2900 \times 0.0$ & $2.43 \pm 0.10^{\mathrm{a}}$ & $1.46 \pm 0.05^{\mathrm{a}}$ & $2.00 \pm 0.11$ & $5.89 \pm 0.14^{\mathrm{a}}$ \\
\hline $2900 \times 0.5$ & $2.56 \pm 0.07^{\mathrm{a}}$ & $1.41 \pm 0.08^{\mathrm{a}}$ & $2.04 \pm 0.10$ & $6.01 \pm 0.11^{\mathrm{a}}$ \\
\hline $2750 \times 0.0$ & $1.89 \pm 0.09^{\mathrm{b}}$ & $1.00 \pm 0.10^{\mathrm{b}}$ & $2.05 \pm 0.12$ & $4.94 \pm 0.13^{\mathrm{b}}$ \\
\hline $2750 \times 0.5$ & $2.40 \pm 0.12^{\mathrm{a}}$ & $1.44 \pm 0.06^{\mathrm{a}}$ & $2.09 \pm 0.07$ & $5.93 \pm 0.10^{\mathrm{a}}$ \\
\hline
\end{tabular}

Means in the same column within the same effect having different letters are significantly different at $\mathrm{P} \leq 0.05$.

Fayoum J. Agric. Res. \& Dev., Vol. 27, No.1, January, 2013 
M.A.A. Abdel-Mageed; et al.

Table (6): Effect of dietary treatments on intestinal viscosity and incidence of pasting vents of Japanese quail at 14 days of age.

\begin{tabular}{|c|c|c|c|c|}
\hline \multirow[b]{3}{*}{$\begin{array}{l}\text { Treatments } \\
(24 \% \text { CP })\end{array}$} & \multirow{2}{*}{\multicolumn{3}{|c|}{$\frac{\text { Intestinal viscosity }(\mathrm{cP})}{\text { Day } 14}$}} & \multirow{3}{*}{$\begin{array}{c}\text { Pasting } \\
\text { vents } \\
(\%)\end{array}$} \\
\hline & & & & \\
\hline & Duodenum & Jejunum & Ileum & \\
\hline \multicolumn{5}{|c|}{ Energy effects } \\
\hline 2900 (kcal/kg diet) & $2.02 \pm 0.09$ & $4.72 \pm 0.17$ & $3.88 \pm 0.11$ & $16.67 \pm 0.22^{\mathrm{A}}$ \\
\hline 2750 (kcal/kg diet) & $1.96 \pm 0.07$ & $4.46 \pm 0.10$ & $3.90 \pm 0.09$ & $11.12 \pm 0.30^{\mathrm{B}}$ \\
\hline \multicolumn{5}{|c|}{ Enzyme effects } \\
\hline Xylam $^{500}(0.0 \mathrm{~kg} / \mathrm{kg}$ diet $)$ & $2.51 \pm 0.10^{\mathrm{A}}$ & $5.33 \pm 0.13^{\mathrm{A}}$ & $4.39 \pm 0.13^{\mathrm{A}}$ & $19.45 \pm 0.24^{\mathrm{A}}$ \\
\hline Xylam $^{500}(0.5 \mathrm{~kg} / \mathrm{kg}$ diet $)$ & $1.50 \pm 0.04^{\mathrm{B}}$ & $3.85 \pm 0.19^{\mathrm{B}}$ & $3.39 \pm 0.10^{\mathrm{B}}$ & $8.34 \pm 0.27^{\mathrm{B}}$ \\
\hline \multicolumn{5}{|c|}{ Interaction } \\
\hline $2900 \times 0.0$ & $2.60 \pm 0.05^{\mathrm{a}}$ & $5.41 \pm 0.11^{\mathrm{a}}$ & $4.45 \pm 0.14^{\mathrm{a}}$ & $22.22 \pm 0.12^{\mathrm{a}}$ \\
\hline $2900 \times 0.5$ & $1.44 \pm 0.02^{\mathrm{b}}$ & $4.02 \pm 0.10^{\mathrm{b}}$ & $3.31 \pm 0.11^{\mathrm{b}}$ & $11.11 \pm 0.31^{\mathrm{c}}$ \\
\hline $2750 \times 0.0$ & $2.41 \pm 0.04^{\mathrm{a}}$ & $5.24 \pm 0.16^{\mathrm{a}}$ & $4.33 \pm 0.10^{\mathrm{a}}$ & $16.67 \pm 0.20^{\mathrm{b}}$ \\
\hline $2750 \times 0.5$ & $1.50 \pm 0.06^{\mathrm{b}}$ & $3.68 \pm 0.12^{\mathrm{b}}$ & $3.47 \pm 0.14^{\mathrm{b}}$ & $5.56 \pm 0.34^{\mathrm{d}}$ \\
\hline
\end{tabular}

Means in the same column within the same effect having different letters are significantly different at $\mathrm{P} \leq 0.05$

Table (7): Effect of dietary treatments on performance of laying Japanese quail from 7 to 19 weeks of age.

\begin{tabular}{|c|c|c|c|c|c|c|}
\hline $\begin{array}{l}\text { Treatments } \\
(20 \% \mathrm{CP})\end{array}$ & $\begin{array}{l}\text { EP } \\
(\%)\end{array}$ & $\begin{array}{c}\text { FI } \\
\text { (g/hen/day) }\end{array}$ & $\begin{array}{l}\mathbf{E W} \\
(\mathrm{g})\end{array}$ & $\begin{array}{c}\text { EN } \\
\text { (No./hen/ } \\
\text { day) }\end{array}$ & $\begin{array}{c}\text { FCR } \\
(\mathrm{g} \mathrm{feed} / \mathrm{g} \\
\mathrm{egg})\end{array}$ & $\begin{array}{c}\text { EM } \\
\text { (g/hen/day) }\end{array}$ \\
\hline \multicolumn{7}{|c|}{ Energy effects } \\
\hline 2900 (kcal/kg diet) & $23.74 \pm 0.05^{\mathrm{B}}$ & $82.66 \pm 0.39^{\mathrm{A}}$ & $0.83 \pm 0.01^{\mathrm{A}}$ & $11.16 \pm 0.02^{\mathrm{A}}$ & $9.09 \pm 0.01^{\mathrm{A}}$ & $2.61 \pm 0.01^{\mathrm{B}}$ \\
\hline 2750 (kcal/kg diet) & $25.96 \pm 0.11^{\mathrm{A}}$ & $79.99 \pm 0.71^{\mathrm{B}}$ & $0.80 \pm 0.01^{\mathrm{B}}$ & $10.54 \pm 0.01^{\mathrm{B}}$ & $8.33 \pm 0.02^{\mathrm{B}}$ & $3.15 \pm 0.02^{\mathrm{A}}$ \\
\hline \multicolumn{7}{|c|}{$\begin{array}{l}\text { Enzyme effects } \\
\end{array}$} \\
\hline Xylam $^{500}(0.0 \mathrm{~kg} / \mathrm{kg}$ diet $)$ & $26.00 \pm 0.10^{\mathrm{A}}$ & $80.22 \pm 0.33^{\mathrm{B}}$ & $0.81 \pm 0.01^{\mathrm{B}}$ & $10.52 \pm 0.01^{\mathrm{B}}$ & $8.43 \pm 0.02^{\mathrm{B}}$ & $3.12 \pm 0.02^{\mathrm{A}}$ \\
\hline $\mathrm{Xylam}^{500}(0.5 \mathrm{~kg} / \mathrm{kg}$ diet $)$ & $23.71 \pm 0.08^{\mathrm{B}}$ & $82.43 \pm 0.52^{\mathrm{A}}$ & $0.83 \pm 0.02^{\mathrm{A}}$ & $11.17 \pm 0.01^{\mathrm{A}}$ & $9.00 \pm 0.02^{\mathrm{A}}$ & $2.64 \pm 0.02^{\mathrm{B}}$ \\
\hline \multicolumn{7}{|c|}{ Interaction } \\
\hline $2900 \times 0.0$ & $24.23 \pm 0.09^{b}$ & $82.53 \pm 1.34^{\mathrm{a}}$ & $0.83 \pm 0.01^{\mathrm{a}}$ & $11.10 \pm 0.02^{\mathrm{a}}$ & $9.10 \pm 0.02^{\mathrm{a}}$ & $2.66 \pm 0.01^{\mathrm{b}}$ \\
\hline $2900 \times 0.5$ & $23.25 \pm 0.05^{\mathrm{b}}$ & $82.79 \pm 1.41^{\mathrm{a}}$ & $0.83 \pm 0.01^{\mathrm{a}}$ & $11.21 \pm 0.02^{\mathrm{a}}$ & $9.08 \pm 0.01^{\mathrm{a}}$ & $2.56 \pm 0.01^{\mathrm{b}}$ \\
\hline $2750 \times 0.0$ & $27.76 \pm 0.10^{\mathrm{a}}$ & $77.91 \pm 1.21^{\mathrm{b}}$ & $0.78 \pm 0.02^{b}$ & $9.94 \pm 0.02^{b}$ & $7.75 \pm 0.03^{b}$ & $3.58 \pm 0.01^{\mathrm{a}}$ \\
\hline $2750 \times 0.5$ & $24.16 \pm 0.07^{b}$ & $82.07 \pm 1.23^{\mathrm{a}}$ & $0.82 \pm 0.03^{\mathrm{a}}$ & $11.13 \pm 0.01^{\mathrm{a}}$ & $8.91 \pm 0.01^{\mathrm{a}}$ & $2.71 \pm 0.02^{\mathrm{b}}$ \\
\hline
\end{tabular}

Means in the same column within the same effect having different letters are significantly different at $\mathrm{P} \leq 0.05$.

FI $=$ Feed intake

$\mathrm{EP}=$ Egg production

$\mathrm{EN}=$ Egg number

EW $=$ Egg weight

$\mathrm{EM}=$ Egg mass

$\mathrm{FCR}=$ Feed conversion ratio 
REFERENCES

A. O. A. C., (1990). Association of Official Analytical Chemists. Official Methods of analysis $15^{\text {th }}$ Ed., published by Assoc. Office. Anal. Chem., Washington, D.C., USA.

Abbott, W.W.; J.R. Couch and R.L. Atkinson, (1969). The incidence of footpad dermatitis in young turkeys fed high levels of soybean meal. Poult. Sci., 48: 2186-2188.

Abdel-Mageed (2012). Effect of using enzymes on performance of Japanese quail fed optimal and sub-optimal energy levels. Egypt. Poult. Sci. Vol (32) (IV) : $865-881$.

Apata, D.F and V. Ojo, (2000). Efficacy of Trichoderma Viride enzyme complex in broiler starters fed cowpea testa-based diets. In Animal Production in New millennium. Challenges and options. Proc. Of 25th NSAP Animal Conference, Michael Okpara University of Agriculture, Umudike, p: 132-134.

Banerjee, G.C., (1992). Poultry, 3 edn. Oxford and IBH pub. Co.Pvt. Ltd. New Dilhi, Bombay, Calcata.

Brenes, A.; M. Smith; W. Guenter and R.R. Marquardt, (1993). Effect of enzyme supplementation on the performance and digestive tract size of broiler chickens fed wheat- and barley-based diets. Poult. Sci., 72: 17311739.

Cowan, W.D; A. Korsbak; T. Hastrup and P.B. Rasmussen, (1996). Influence of added microbial enzymes on energy and protein availability of selected feed ingredients. Anim. Feed Sci. Technol., 60: 311-319.

Duncan, D.B., (1955). Multiple range and multiple F- test. Biometrics, 11: 1-42.

Feed Composition Tables for Animal \& Poultry Feedstuffs Used in Egypt (2001). Technical Bulletion No. 1, Central lab for Feed and Food; Ministry of Agriculture, Egypt.

Gracia M.I.; M.J. Aranıbar; R. Lazaro; P. Medel and G.G. Mateos, (2003). Alpha-amylase supplementation of broiler diets based on corn. Poult. Sci., 82: 436-442.

Hill, F.W. and R. Renner, (1960). The metabolizable energy of soybean oil meals, soybean millfeeds and soybean hulls for the growing chick. Poult. Sci., 39: 579-583.

Hill, F.W.; D.L. Anderson; R. Renner and L.B. Carew Jr., (1960). Studies on the metabolizable energy of grains and grain products for chickens. Poult. Sci., 39: 573-579.

Jackson, M.E.; K. Geronian; A. Knox; J. McNab and E. McCartney, (2004). A dose response study with the enzyme $\beta$-mannanase in broilers provided with corn-soybean meal based diets in the absence of antibiotic growth promoters. Poult. Sci., 83: 1992-1996.

Jensen, L.S.; R. Martinson and G. Schumaier, (1970). A foot pad dermatitis in turkey poults associated with soybean meal. Poult. Sci., 49: 76-82.

Kidd, M.T.; G.W. Morgan, Jr.; C.J. Price; P.A. Welch and E.A. Fontana, (2001). Enzyme supplementation to corn and soybean meal diets for broilers. J. Appl. Poult. Res., 10: 65-70.

Knudsen, K.E., (1997). Carbohydrate and lignin contents of plant materials used in animal feeding. Animal Feed Science and Technology, 67: 319338.

Knudsen, K.E., (2001). The nutritional significance of dietary fiber analysis. Animal Feed Science and Technology, 90: 3-20.

Kocher, A.; M. Choct; G. Ross; J. Broz and T.K. Chung, (2003). Effect of enzyme combinations on apparent metabolizable energy of corn-soybean meal based diets in broilers. J. Appl. Poult. Res., 12: 275-283.

Fayoum J. Agric. Res. \& Dev., Vol. 27, No.1, January, 2013 
Lamptey, A.; T.F. Brihkhaus; J.A. Greaves; E.A. Fontana and G.M. Smith, (2001). Method for increasing breast meat yields in poultry. US. Pat. No. 6, 174, 558.

Marsman, G.J.P.; H. Gruppen; A.F.B. van der Poel; A.F. Kwakkel; M.W.A. Verstegen and A.G.J. Vogagen, (1997). The effect of thermal processing and enzyme treatments of soybean meal on growth performance, ileal nutrient digestibilities, and chyme characteristics in broiler chicks. Poult. Sci., 76: 864-872.

North, M.O., (1981). Commercial Chicken Production Manual, $2^{\text {nd }}$ Edition. AVI Publishing Company INC, USA.

Nworgu, F.C, E.A. Adebowale, O.A. Oredein and A. Oni, (1999). Prospects and economics of broiler production using two plant protein sources. Trop. J. Anim. Sci., 2: 159-166.

Potter, L.M. and E.D. Matterson, (1960). Metabolizable energy of ingredients for chickens. Rep. 9. Conn. Agr. Exp. Sta. Program, New Haven CT

Sibbald, I.R. and S.J. Slinger, (1962). The metabolizable energy of materials fed to growing chicks. Poult. Sci., 41: 1612-1613.

Singh, R.A., (1990). Poultry Production, 3rd edition. Kalyany. Publishers, New Delhi, Ludhiana.

SPSS (1993). SPSS Statistical software Package for the social sciences. 2 nd ed. HA33-N48. McGrow-Hill, Inc., USA.

Steel, R.G.D. and J.H. Torrie, (1980). Principles and procedures of statistics: A Biometrical $2^{\text {nd }}$ ed. McGraw-Hill Book Co., Inc., New York, USA

Tahir, M.; F. Saleh; A. Ohtsuka and K. Hayashi, (2005). Synergistic effect of cellulose and hemicellulase on nutrient utilization and performance in broilers fed a corn-soybean meal diet. J. Anim. Sci., 76: 559-565.

Van der Klis, J.D.; A.Van Voorst and C. Van Kruyningen, (1993). Effect of a soluble polysaccharide (carboxymethyl cellulose) on the physicochemical conditions in the gastrointestinal tract of broilers. Br. Poult. Sci., 34: 971-983.

Waldroup, P.; C. Keen; F. Yan and K. Zhang, (2006). The effect of levels of alpha-galactosidase enzyme on performance of broilers fed diets based on corn and soybean meal. J. App. Poult. Res., 15(1): 48-57.

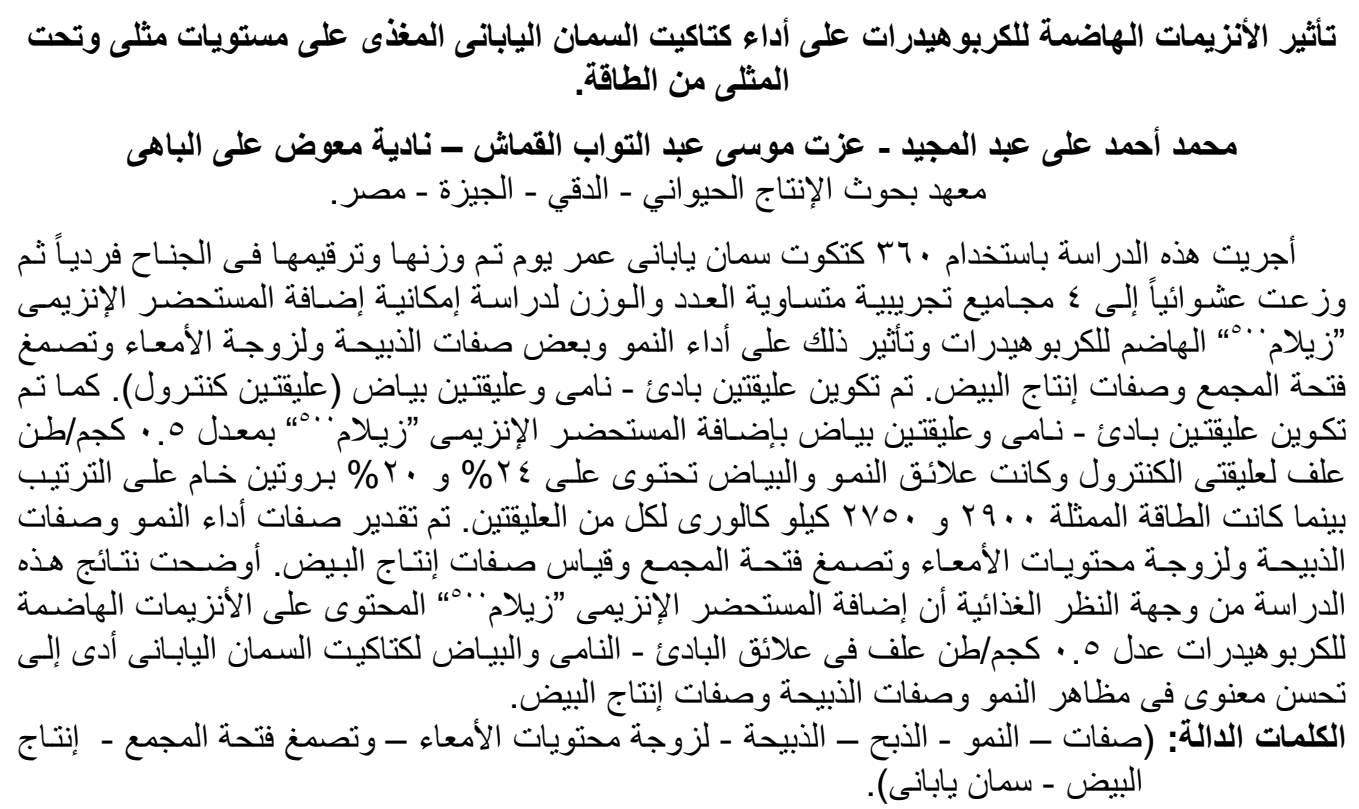

Fayoum J. Agric. Res. \& Dev., Vol. 27, No.1, January, 2013 